\title{
Information technology and the
} empowerment of social workers in government hospitals in Cairo Governorate, Egypt

\section{Mohammed Abu-Elhamd Sayed Ahmed (PhD)}

Associate Professor of social planning, Department of Social Work and community development, Faculty of Education - Al- Azhar

University

\section{Mohammed Abdel Latif Mohamed Ali (PhD)}

Associate Professor, Department of Social Planning Faculty of

Social Work - Helwan University 


\section{Information technology and the empowerment of social workers} in government hospitals in Cairo Governorate, Egypt

\section{Mohammed Abu-Elhamd Sayed Ahmed (PhD)}

Associate Professor of social planning, Department of Social Work and community development, Faculty of Education - Al- Azhar University

\section{Mohammed Abdel Latif Mohamed Ali (PhD)}

Associate Professor, Department of Social Planning Faculty of

Social Work - Helwan University

\section{Abstract:}

This study aims to determine the impact of information technology, as an element of social planning, used for the empowerment of social workers in government hospitals in Cairo, and to identify the obstacles faced. The population consisted of 138 social workers working in 54government hospitals in the Cairo governorate, during the period $28 / 12 / 2017$ to $15 / 2 / 2018$. The study found that information technology has a significant impact on all dimensions of empowerment. It has also shown that there is little application by social workers in the use of information technology, and illustrated that social workers have insufficient training in the use of information systems. Therefore, the study suggests that professional training units must consider including IT \& communication skills in all training plans.

Keywords: Information technology- empowerment-social workersgovernment hospitals-social planning

\section{Introduction:}

Information and communication technologies (ICTs) are widespread in developed countries and considered integral to efforts to build social, political and economic participation in developing countries (Perron, et al,2010, p.67). Also, information and communication technology (ICT) can help developing countries tackle a wide range of health, social and economic problems. By improving access to information and enabling communication, ICT can play a role in reaching UN Millennium Development Goals, such as the elimination of extreme poverty, combating serious disease and achieving universal primary education and gender equality(UK Parliamentary Office for Science \&Technology, March 2006 Number 261,P.1).Social workers need to be able to use the latest information and communication technologies to provide services, keep records, 
analyze data for funding and program evaluation, to communicate and to participate in distance education and service provision(Wager,2016, p.584).

Social planning highlights the application of rational problemsolving techniques and data-driven approaches to identify, determine, and help coordinate services for target populations. Social planning is carried out by a myriad of organizations - from federal agencies to community organizations - attempting to solve problems ranging from child welfare to aging(Sager,2008, p.57).

The pace and reach of today's innovation in fields including information technology, space exploration and genetic engineering, often come from the transmission of skills promoted by the free exchange of ideas at the meeting points of previously separate fields of knowledge(Heywood, 2011,p.96).

The launching of the scientific and technological revolution represents the decisive factor in the movement of the world's business systems, with the achievement of countless productive capacities. Successive scientific and technological revolutions have led to the elimination of traditional constraints, according to a study by(Hammad,2008,p.197), and, furthermore, highlighted the achievements of new technologies in overcoming the limitations of space, time, and the scarcity of raw materials and natural resources. These scientific and technological developments have had a significant impact in the formation of human resources in contemporary organizations in terms of quantity and quality (Zidane, 2002 , p.122). The required numbers of workers in general have become far fewer due to the replacement of individuals with modern technologies. The areas of expertise, skills levels and qualifications required from the members of contemporary organizations varied widely according to (Ibrahim, 2003, p.83). This has resulted in significant changes in the number patterns, training and development of human resources, as well as the overall human resources management systems, in terms of performance design, culmination and measuring processes of performance evaluation. This was noted by the study of (Tawfiq, 2007).

ICT (including mobile devices) is characterized by the integration of technology into communications and has revolutionized how individuals interact. ICT has led to transformational changes in social services and other disciplines, including education and psychology. Although increasingly common in the practice of 
traditional social services face to face, the research lacks the informal use of ICTs by practitioners with clients, which usually occurs between sessions, and at home, as an unplanned assistant (and unlicensed in many cases) to the traditional face of direct practice (Mishna. et al , 2016 , P.45)

As a result of the high scientific and cognitive level of social workers in contemporary social and health institutions, the tendency to empower social workers and involve them in carrying out decisionmaking responsibilities has increased. The scientific and technological revolution has been an important factor in the acquisition of many skills and expertise by social workers, as well as the provision of customer data enabling social workers to identify problems. This emphasizes the importance of transition to a new awareness of human resources commensurate with contemporary situations (Khattab,2009).

The internet and other communication technologies have changed many geographical limitations by allowing workers to access professional information and communicate more effectively. This is confirmed by the WebTV Pal Talk study, which highlights the importance of using communication technologies in the education of social workers so that they may keep up with the technology era. The development of the tools and utilities used is critical in enabling social workers to identify the objectives of operations and outcomes in partnership with different populations and communities more effectively, as confirmed by(Boehm, A., \& Staples, L.,2002,Pp.449$450)$. However, social workers may face multiple obstacles in the use of information technology (Mustafa ,2011,p.188).

Hill and Shaw 2011 remarked that an additional way of viewing ICT within social work is to express it as a part of direct practice - of assessment, planning, intervention, recording, reviewing or evaluating. For example, in the health field, 'telemedicine' has been prominent for some time. The expression 'social work' has not yet surfaced, but the idea of telecare is beginning to figure (Hill \& Shaw, 2011, p.65).

The concept of "empowerment" has been widely accepted in recent years and is now used extensively in the field of social work (Gutierrez, Parsons, \& Cox;1998; Lee, 1994; Simon, 1994; Solomon, 1976). ( Roberts \& Greene,2002,p.401). This approach, which was first developed in the 1970s, is increasingly used in welfare policy, social programs, or direct intervention, and replaces the traditional 
therapist-client model of the helping relationship (Gutierrez, 1992; Pinderhughes, 1983; Rappaport, 1981; Shera\& Page, 1995) (Boehm, A., \& Staples, L.,2002,P.449).

The research then dealt with the impact of information technology on the empowerment of social workers in government hospitals in the Cairo governorate

\section{Research Problem:}

1) The research problem is determined: what is the extent of using IT by social workers in government hospitals in Caro?

2) : what is the extent of empowerment for social workers in government hospitals in Caro?

3) What is the relationship between Information Technology (IT) and the empowerment of social workers in government hospitals in Cairo Governorate, -Egypt?

4) What are the social planning indicators for maximizing the degree of empowerment for social workers workingin government hospitals in Cairo Governorate,regarding IT?

\section{Research Objectives:}

The objectives of the study are:

- Describe the information technology (IT) used in public hospitals in Cairo.

- Determine the impact of the use of IT on the dimensions of the empowerment of social workers in government hospitals in Cairo.

- Identify obstacles faced by social workers in government hospitals, in the use of IT.

- Reach a set of planning indicators for maximizing the degree of empowerment for social workers working in Cairo Governorate hospitals, regarding IT.

\section{Research Hypotheses:}

The current study attempts to test the following hypotheses:

- First hypothesis: There is a significant relationship between the use of information technology and the efficiency of social workers in government hospitals.

- The second hypothesis: There is a significant relationship between the use of information technology and the ability of social workers to make decisions at government hospitals.

- Third hypothesis: There is a significant relationship between the use of information technology and the liabilityof the work of social workers at government hospitals. 
- Fourth hypothesis: There is a significant relationship between the use of information technology and the impact of social workers on decisions made in government hospitals..

\section{Concepts of the Study:}

Associated terminologies used within the research are :

\section{Information technology:}

The technology involving the development, maintenance and use of computer systems, software, and networks for the processing and distribution of data (Merriam Webster, 2018). Social workers' use of technology is proliferating; technology has transformed the nature of social work practice and greatly expanded social workers' ability to assist people in need(NASW,2017, p.1).

The operative definition of the information technology for social workers in governorate hospitals in Cairo is:

- Using modern communication (Social Media ) and information technology for service delivery for patients

- The ability to use C \& IT methods and techniques in professional communications, and data storage and retrieval

- Using modern communication ( Social Media ) and information technology in e- therapy and intervention, eCase study, information searching, e- diagnosis, helping process and e-therapy and intervention

\section{Empowerment:}

The act or action of empowering someone or something; the granting of the power, right, or authority to perform various acts or duties (Webster, 2018). Empowerment has become a familiar term within many development agencies. Empowerment objectives also appear with increasing frequency in policy documents issued by governments, especially strategy papers dealing with poverty reduction(Alsop, 2006, p.1). According to the dictionary of social work \&social care (2013) empowerment is the process through which people who lack power become more powerful, not in the sense of having power over others but in working towards achieving their aims (Harris \& White:2018, p.:211).

Empowerment is to give employees the appropriate powers, responsibilities and full freedom to choose the appropriate methods required to perform their work without interference from the administration. The role of the administration is to provide all the necessary resources and the appropriate work environment, and to qualify workers technically, psychologically and tactically, to give 
them absolute confidence to achieve their work aims. Empowerment is, therefore, about providing social workers with the appropriate powers and responsibilities, as well as complete freedom, to choose appropriate methods of performing their work and providing services to hospital clients.

Perceived empowerment includes four dimensions (efficiency - ability to choose - responsibility - influence).

Empowerment in this study can be determined as follows:

- The efficiency of social workers in government hospitals.

- The ability of social workers to make decisions at government hospitals.

- The importance of the work of social workers at government hospitals.

- The impact of social workers on decision-making in government hospitals.

\section{Theoretical Framework:}

The generalist practice of the social work profession depends mainly on social system theory and ecological theory. They are theoretical frameworks that provide a deeper and comprehensive vision about the way different systems interact. Selecting scientific theories is carried out in the light of many criteria such as the requirements of field practice and the aims that the profession seeks to achieve (Dandrawy, 2001, p.60).

\section{Social systems theory:}

Social systems theory is considered one of the main framework theories for the generalist practice of social work. It is a broad tool for thinking about and understanding how social life progresses and the relationships between systems in society. Every system consists of inputs, transformations processes, outputs, feedback and interaction with the surrounding environment. Systems are classified into open and closed systems. Open Systems, for example, are the systems that receive outside inputs according to their needs and limits. Such a system finds support from its external context to maintain its balance through internal and external adaptation. An agency or organization might consider an open social system that approaches interaction, interdependency, and exchange with the external community according to its needs. Social Systems theory refers to the concept of a social role and its significance in the system framework. The social role refers to a system of behaviors that are linked to the person who occupies a certain position or job in the organization. This moral 
system is composed of behaviors, human relations and professional relations that are connected with the activities and different responsibilities of the role and how to perform it. Accordingly, each system has a role to play, and every member of this system has a role to play, which contributes towards achieving the system's aims (Suleiman ,et al., 2005, p.292).

\section{Communication theory:}

Communication is the process by which knowledge is passed from one person to another.

Communications means:

- Direct means such as personal interviews - field visits - and participation in public events.

- Indirect means such as readable media including newspapers audio - visual - images - computer (Abdel - Fattah, 2011, p.168).

Communication Elements:

- The content message or content to be transmitted from the sender to the receiver may be information or ideas.

- The sender is the entity from which the message is sent, that the owner wishes to convey to the future, and may be a person or institution.

\section{Fields:}

Study Place: (54) government hospitals inside the Cairo governorate2-

\section{Time:}

The study applied in the period from 28/12/2017to15/02/2018.

\section{Population:}

A comprehensive record Of all social workers working in 54 government hospitals in Cairo governorate, The study applied to 138 social workers $(\mathrm{N}=138)$ there were (38 hospitals each of them includes 3 social worker $)$, there were ( 8 hospitals each of them includes only 2 social worker ), there were ( 8 hospitals each of them includes one social worker)

Statistical analytical method :

Data were processed through the computer using the program (SPSS. V.21.0), following statistical processes were applied :

- Duplicates\& percentages to describe the characteristics of the study population 
- The arithmetic mean(M) : to judge the level of relationship between IT, and Empowerment for social workers in governorate hospitals in Cairo Using Likert Quintet scale.

- Standard deviation(SD) : to know the extent of dispersion or non- dispersion of social workers' responses it also helps to rank the terms with the arithmetic mean, the less SD takes higher order .

- Coefficient of Alpha (Cronbach) Stability.

- Simple Regression analysis To study the effect of one variable on a single dependent variable (the Study hypotheses)

- Pearson Correlation Coefficient (R): to test the relationship between two quantitative variables as well as the relationship of the independent variable in the dependent variable,(test hypotheses )

\section{Research methodology and tools:}

1 Type of the Study: Due to the nature and the requirements of the subject, the study relies on descriptive approach, the research is considered a descriptive study, a case study method was implemented with social workers working in governmental hospitals in Cairo Governorate., with the intent to obtain sufficient data and information that can be used to study social workers working in government hospitals in Cairo Governorate.

- Tools: A questionnaire about " information technology and Empowerment of social workers in hospitals in Cairo Governorate" was used with social workers working in government hospitals in Cairo, to describe the relationship between the role of( IT ) and Empowerment for them

\section{Validity and reliability of the study tool:}

- Face validity: the scale of(40) Items of(IT) used by social workers in government hospitals, was presented to (10)specialist reviewers in social work and experts in IT and professional empowerment in Cairo. They examined the scale and expressed their opinions on the stability of the scale items that contributed to the aims of study. All modifications suggested were made, the approval degree was at least $80 \%$ for each item.

- Internal consistency; the measurement was applied in its final form to a sample of (15) social workers working in a 


\begin{tabular}{||lcc|}
\hline \multicolumn{2}{|l|}{ Egyptian Journal of Social Work (EJSW) } & \multicolumn{1}{c|}{ http://ejsw.journals.ekb.eg } \\
Print ISSN: 2356-9204 & Online ISSN: 2356-9212 & Vol 8, Issue 1, June 2019 \\
\hline
\end{tabular}

government hospital in another governorate. The correlation coefficients were calculated by the index to which they belong. The correlation coefficients between the scale dimensions and the scale as a whole were calculated, as shown in the following:

\section{Reliability of the scale:}

Table (1) Results of the reliability of the questionnaire using the coefficient (Alpha - Cronbach)

\begin{tabular}{|c|c|c|c|c|}
\hline$\overline{\mathrm{Sr}}$ & \multicolumn{2}{|c|}{ First variable; Information Technology: } & Number & (Alpha- \\
\hline 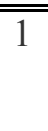 & $\overline{\text { Dimension1 }}$ & $\begin{array}{l}\text { using of modern communication } \\
\text { and information technology for } \\
\text { service delivery for patients }\end{array}$ & $\overline{5}$ & 0.84 \\
\hline 2 & Dimension2 & $\begin{array}{l}\text { The ability to use C \& IT } \\
\text { methods and techniques in } \\
\text { professional communications, } \\
\text { data storage and retrieval }\end{array}$ & 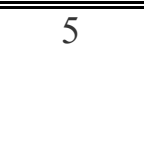 & 0.80 \\
\hline \multirow[t]{3}{*}{3} & Dimension3 & $\begin{array}{l}\text { The ability to use C \& IT } \\
\text { methods and techniques in Case } \\
\text { study, information searching, } \\
\text { diagnosis, helping process, } \\
\text { therapy and intervention }\end{array}$ & $\overline{6}$ & 0.85 \\
\hline & & Dimensions as a whole & 16 & 0.83 \\
\hline & \multicolumn{4}{|c|}{ Second variable; Empowerment } \\
\hline 1 & Dimension1 & $\begin{array}{l}\text { The ability of social workers to } \\
\text { make decisions at government } \\
\text { hospitals. }\end{array}$ & 6 & 0.92 \\
\hline 2 & Dimension2 & $\begin{array}{l}\text { The efficiency of social workers } \\
\text { in government hospitals. }\end{array}$ & $\overline{6}$ & 0.82 \\
\hline 3 & "Dimension3 & $\begin{array}{c}\text { The liabilityof the work of } \\
\text { social workers at government } \\
\text { hospitals. }\end{array}$ & 6 & 0.86 \\
\hline \multirow[t]{3}{*}{4} & Dimension & $\begin{array}{l}\text { The impact of social workers on } \\
\text { decision-making in government } \\
\text { hospitals. }\end{array}$ & $\overline{6}$ & 0.85 \\
\hline & & Dimensions as a whole & 24 & 0.86 \\
\hline & \multicolumn{2}{|c|}{ " questionnaire as a whole } & 40 & 0.85 \\
\hline
\end{tabular}

Table (1) above shows that most of the coefficients of the variables have a high degree of reliability and can, thus, be relied upon and the tool is finalized. 
The number of forms sent was 138 and the questionnaire was divided into the following:

1. Part I Group of Items 1 to 16 representing Information Technology .

a. Items 1 to 5 represent (dimension of The efficiency of social workers in using modern communication and information technology for service delivery for patients)

b. Items 5 to 10 represent (dimension of . The ability to use $\mathrm{C} \&$ IT methods and techniques in professional communications, data storage and retrieval, information

c. The ability to use C \& IT methods and techniques in Case study, information searching, diagnosis, helping process, therapy and intervention

2. Part II Group of Items 17 to 40 represents the four dimensions of Empowerment. The five-dimensional Likert scale is used as follows:

a.Items 17 to 22 represent (dimension of The ability of social workers to make decisions)

b. Items 23 to 28 represent (dimension of The efficiency)

c.Items 29 to 34 represent(dimension The liabilityof the work).

d. Items 35 to 40 represent (dimension of The impact of social workers on decision-making in government hospitals

3. Part III Collection of Explanatory Questions.

4. Part IV Explanatory Data

.Results:

Table (2) demographic variables $(\mathrm{N}=138)$

\begin{tabular}{|c|c|c|c|}
\hline \multirow{2}{*}{$\underline{\mathrm{Sr}}$} & Demographic variables & Repetition & percentage \\
\hline & Gender & & \\
\hline 1 & Male & 40 & 29.00 \\
\hline \multirow[t]{2}{*}{$\underline{\underline{\underline{2}}}$} & Female & 98 & "71.00 \\
\hline & Total & 138 & \%100 \\
\hline$\underline{\mathrm{Sr}}$ & Social status & & \\
\hline 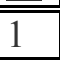 & Single & 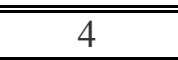 & 03.00 \\
\hline \multirow[t]{3}{*}{2} & Married & 130 & 94.00 \\
\hline & Divorced & 44 & 03.00 \\
\hline & Total & 138 & 100.00 \\
\hline$\underline{\mathrm{Sr}}$ & Age & & \\
\hline$\overline{\overline{1}}$ & Less than 30 & 8 & 05.80 \\
\hline$\underline{\underline{2}}$ & $30-40$ & 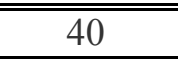 & 29.00 \\
\hline
\end{tabular}


Print ISSN: 2356-9204 Online ISSN: 2356-9212 Vol 8, Issue 1, June 2019

\begin{tabular}{|c|c|c|c|}
\hline \multirow{2}{*}{$\underline{\mathrm{Sr}}$} & Demographic variables & Repetition & percentage \\
\hline & Gender & & \\
\hline 3 & $40-50$ & 60 & 43.50 \\
\hline \multirow[t]{2}{*}{$\overline{\overline{4}}$} & $50-60$ & 30 & 21.70 \\
\hline & Total & 138 & $\% 100$ \\
\hline$\underline{1}$ & Medium Institute & 32 & 23.18 \\
\hline$\underline{\underline{\underline{2}}}$ & Bachelor & 98 & 71.00 \\
\hline$\underline{3}$ & Master degree & 8 & 06.00 \\
\hline & Total & 138 & \% \%100 \\
\hline
\end{tabular}

The above table shows the demographic variables of the study sample since the female group is the largest percentage that may be because this field is more suitable for them, and the largest percentage is in the age group (40-50) that reflects the element of experience in professional practice, the table also shows that the majority of the social workers are married, in terms of qualify the largest percentage is in the bachelor, and the least percentage is in the Master degree. That may be because they have no time or enough money for post-graduation studies

\section{Results related to the first research question :}

"What is the extent of using IT by social workers in government hospitals in Caro?"

Table (3) shows the means and the standard deviations of the dimensions and the overall measure of Variableno (1) information technology

\begin{tabular}{||c||c|c||c||}
\hline \multicolumn{1}{|c||}{ dimension } & mean & $\begin{array}{c}\text { standard } \\
\text { deviation }\end{array}$ & Rank \\
\hline \hline $\begin{array}{l}\text { using of modern communication and information } \\
\text { technology for service delivery for patients }\end{array}$ & 308711 & 1.3318 & 3 \\
\hline \hline $\begin{array}{l}\text { The ability to use C \& IT methods and techniques } \\
\text { in professional communications, data storage and } \\
\text { retrieval }\end{array}$ & .3 .978 & 1.22618 & 1 \\
\hline \hline $\begin{array}{l}\text { The ability to use C \& IT methods and techniques } \\
\text { in Case study, information searching, diagnosis, } \\
\text { helping process, therapy and intervention }\end{array}$ & 3.6868 & 1.04229 & 2 \\
\hline \hline Dimensions as a whole & 3.8456 & 1.197 & .1 \\
\hline \hline
\end{tabular}

Table above shows that the degree of influence of information technology where the means increase The total mean is 3.8456 with a standard deviation of 1.197 , the dimension of The ability to use C \& IT methods and techniques in professional communications, data storage and retrieval was in the first order 3.978, and with a standard deviation 
of 1.226, that may be because the Technological Revolution ant its affects on professional communication, then the dimension of The ability to use C \& IT methods and techniques in Case study, information searching, diagnosis, helping process with arithmetic mean 3.6868with a standard deviation of 1.04229, and finely the dimension of using modern communication and information technology for service delivery for patients with arithmetic mean 308711 with a standard deviation of 1.3318 ,

\section{Results related to the second research question :}

"What is the extent of empowerment for social workers in government hospitals in Caro?"

Table (4) shows the mean and the standard deviation of the dimensions and the overall measure of Variable no (2)

empowerment

\begin{tabular}{|c|c|c|c|}
\hline S & Variable & mean & $\begin{array}{l}\text { standard } \\
\text { deviation }\end{array}$ \\
\hline 1 & Efficiency dimension & 3.8601 & 1.16930 \\
\hline 2 & The ability to make decision dimension & 3.2972 & 1.00837 \\
\hline 3 & Responsibility dimension & 3.6572 & 1.32252 \\
\hline 4 & $\begin{array}{l}\text { The impact of social workers on } \\
\text { decision-making dimension }\end{array}$ & 3.4929 & 1.21521 \\
\hline 5 & Dimensions as a whole & 3.5768 & 1.08827 \\
\hline
\end{tabular}

Table (3)above shows the increase in the perceptions of social workers, to some extent, on the efficiency dimension, where the arithmetic mean is higher than the average score of the scale (three points). The mean is 3.8601 with a standard deviation of 1.16930 .

There was an increase in the perceptions of social workers, to some extent, on the ability of the select dimension, where the arithmetic mean is higher than the average score (three points). The mathematical average was 3.2972 with a standard deviation of 1.00837.

There was an increase in the perceptions of social workers, to some extent, ${ }_{2}$ on the responsibility dimension, where the arithmetic mean is higher than the mean score of the scale (three points). The arithmetic mean was 3.6572 with a standard deviation of 1.32252 .

There was an increase in the perceptions of social workers, to some extent, on the effect dimension, where the arithmetic mean is higher than the mean score of the scale (three points). The arithmetic 
mean was 3.4929 with a standard deviation of 1.21521 . this result answered question NO (2) of the study

\section{Results related to the third research question ;}

"What is the relationship between Information Technology (IT) and the empowerment of social workers in government hospitals in Cairo Governorate, -Egypt?"

Table (5) shows the impact of information technology on efficiency

\begin{tabular}{|c||c||c||c||c||}
\hline $\begin{array}{c}\text { Pearson } \\
\text { correlation } \\
\text { coefficient }\end{array}$ & $\begin{array}{c}\text { The } \\
\text { coefficient of } \\
\text { determination }\end{array}$ & significance & $\begin{array}{c}\text { Spearman } \\
\text { correlation } \\
\text { coefficient }\end{array}$ & significance \\
\hline \hline 0.328 & 0.112 & 0.1001 & 0.262 & 0.002 \\
\hline
\end{tabular}

Table(4) shows that there is a statistically significant relationship at level of (0.01) between the two variables,(IT\& dimension of efficiency ) This may be because there is a direct relationship between these variables and that makes us accept the First hypothesis: There is a significant correlation relationship between the use of information technology and the efficiency of social workers in government hospitals this result agrees with study by(Hammad, Samia Ibrahim,2008),

Table (6) shows the impact of IT on the ability to make decisions

\begin{tabular}{|r||c||c||c||c||}
\hline $\begin{array}{c}\text { Pearson } \\
\text { correlation } \\
\text { coefficient }\end{array}$ & $\begin{array}{c}\text { The } \\
\text { coefficient of } \\
\text { determination }\end{array}$ & significance & $\begin{array}{c}\text { Spearman } \\
\text { correlation } \\
\text { coefficient }\end{array}$ & significance \\
\hline \hline 0.351 & 0.130 & 0.001 & 0.286 & 0.003 \\
\hline
\end{tabular}

Table (5) above shows that there is a significant relationship between the two variables, it is a direct relationship, so that we accept The second hypothesis: There Is a significant positive relationship between the use of information technology and the ability of social workers to make decisions at government hospitals

\section{Table (7) the impact of IT on liability}

\begin{tabular}{|c|c|c|c|c|}
\hline $\begin{array}{c}\text { Pearson } \\
\text { correlation } \\
\text { coefficient } \\
\end{array}$ & $\begin{array}{c}\text { The } \\
\text { coefficient of } \\
\text { determination }\end{array}$ & significance & $\begin{array}{l}\text { Spearman } \\
\text { correlation } \\
\text { coefficient }\end{array}$ & significance \\
\hline 0.263 & 0.087 & 0.004 & 0.171 & 0.05 \\
\hline
\end{tabular}

It is clear from the previous table that there is a significant relationship between the two variables, which is a direct relationship that makes us accept the Third hypothesis: There is a significant 
positive relationship between the use of information technology and the liabilityof the work of social workers at government hospitals.

Table (8) the impact of information technology on the impact of social workers at government hospitals.

\begin{tabular}{|c|c|c|c|c|}
\hline $\begin{array}{l}\text { Pearson } \\
\text { correlation } \\
\text { coefficient }\end{array}$ & $\begin{array}{c}\text { The } \\
\text { coefficient of } \\
\text { determination }\end{array}$ & significance & $\begin{array}{l}\text { Spearman } \\
\text { correlation } \\
\text { coefficient }\end{array}$ & significance \\
\hline 0.341 & 0.116 & 0.000 & 0.354 & 0.004 \\
\hline
\end{tabular}

Table (8)above shows that there is a significant relationship between the two variables, which is a direct relationship. That makes us accept the fourth hypothesis: There is a significant relationship between the use of information technology and the impact of social workers at government hospitals.

Table (9) the impact of information technology on the empowerment of social workers

\begin{tabular}{||c||c||c||c||c||}
\hline $\begin{array}{c}\text { Pearson } \\
\text { correlation } \\
\text { coefficient }\end{array}$ & $\begin{array}{c}\text { The } \\
\text { coefficient of } \\
\text { determination }\end{array}$ & significance & $\begin{array}{c}\text { Spearman } \\
\text { correlation } \\
\text { coefficient }\end{array}$ & significance \\
\hline \hline 0.346 & 0.119 & 0.001 & 0.254 & 0.005 \\
\hline
\end{tabular}

The previous table shows that there is a significant relationship between the variables, which is a direct relationship between the use of information technology and the empowerment of social workers at government hospitals .

\section{Discussion:}

- The study sought to test hypotheses to find out if there is a correlation between the use of information technology and the empowerment of social workers in government hospitals through different dimensions of empowerment; dimensions of efficiency, ability to make decisions, and dimensions of responsibility, and their impact on decisions made within the government hospitals in which they work.

The study found that there is a significant correlation between information technology and the different dimensions of empowerment (efficiency, ability to choose, responsibility, and influence on decisions), but to varying degrees.

It also become apparent how weak the application of information technology was by social workers, due to the lack of training courses on modern technology. This was confirmed by the study of Ibrahim Man dour 2011, where she explained that one of the 
most important obstacles to the success of employees in educational departments is the lack of computer training courses and the lack of effective interaction between all departments of hospitals. This may bedew to waiting for traditional transition of information rather than utilizing information technology. This is confirmed by the theory of communication, in particular the means of indirect communication, in the transmission of knowledge and information from one institution to another or from person to person.

Social workers face many obstacles to benefiting from information technology. For example, the lack of electronic devices available in departments of social work, as confirmed by the study Mustafa, F, Ramadan (2011) who explained that one of the difficulties facing the use of information technology is the lack of electronic devices in local councils in the provinces. In addition to this is the lack of maintenance of electronic devices in hospitals, leading to the destruction of many before full use is made of information technology.

There is no development of tools, devices or computer programs, as called for by the study of Boehm, A., \& Staples, L. (2002), which described the need to develop tools which would enable social workers to determine the goals of empowerment.

Although information technology has contributed to the emergence of new social workers, there is some concern amongst specialists in government hospitals about the lack of modern possibilities.

Social workers also believe that failure to disseminate information on an ongoing basis may lead to inefficiency in hospital work.

\section{Results related to the fourth research question ;}

" What are the social planning indicators for maximizing the degree of empowerment for social workers working in government hospitals in Cairo Governorate, regarding IT?" 
A proposal of social planning indicators for achieving empowerment regarding the use of IT for social workers working in governorate hospitals:

\section{1- Macro level;}

- There must be a policy for professional development that sets communication skills and information technology skills at the top of its priorities.

- Development of programs, applications and networks to achieve communication between hospitals, and departments within hospitals, which will benefit from the exchange of disease files, and an increase in the performance of social workers and the services they provide to government hospitals.

- Importance given to the political advocacy for human rights and needs of social workers working in governmental hospitals, regarding communication and IT skills.

- Importance given to the human aspect of information systems, and work undertaken to absorb any new technology in this field, so that development depends on the degree of absorption of this technology by social workers.

\section{2- Mezzo level;}

- There must be a specialist unit for quality and accountability assurance training programs that make communication and information technology skills a course for professional mobility.

3- Micro level;

- The roles of social workers working in governmental hospitals must be specified according to job descriptions.

- Social workers must be satisfied about teamwork, organization climate, and the quality of their working life. Their training needs must be continuously and sustainably assessed.

Social workers' sense of empowerment must be increased by allowing them to participate in decision-making and problem solving in innovative ways. 


\section{References:}

Albert R. Roberts,\& Gilbert J. Greene (2002)Social Workers' Desk Reference, New York: Oxford University Press,p.401

Alsop. Ruth (2006) Empowerment in Practice: From Analysis to Implementation, USA, NY, The World Bank, P:1.

Belle Feuillet, G., Martin, R. R. and Buck, M. P. (2005) 'from pedagogy to technology in social work education: A constructivist approach to instructional design in an online, competency-based child welfare practice course', Child and Youth Care Forum, 34, pp. 371-379.

Boehm, A., \& Staples, L. (2002). The Functions of the Social Worker in Empowering: The Voices of Consumers and Professionals. Social Work, 47(4), Pp. 449-450. Retrieved from http://www.jstor.org/stable/23718753

Mishna, Faye, Fantus, Sophia and McInroy, Lauren (2016) Informal Use of Information and Communication Technology: Adjunct to Traditional Face-to-Face Social Work Practice $\}$, volume, journal of \{Clinical Social Work Journal

González-Gómez, F., Guardiola, J., Martín Rodríguez, Ó. Montero, A., and Miguel, Á. (2012). Gender differences in electronic learning satisfaction. Computers and Education, 58(1), 283-290.

Hammad. I ، Hassan(2008) Information Technology and Modern Management, Master Thesis published - Cairo University - Faculty of Commerce.

Harris. J, White. V. (2018) dictionary of social work \&social care, UK, Oxford University. Press, P. 211.

Heywood,P. (2011) Community Planning: Integrating Social and Physical Environments. UK, Blackwell John Wiley\& Sons Ltd: 96. Mustafa, F, Ramadan. (2011). Use of the information technology in determining priorities of welfare services in deteriorated urban areas. (MA) - Helwan University. Faculty of Social Work. Department of Social Planning.

Hill. A , \& Shaw I, (2011) Social Work and ICT, London, SAGE publications Ltd, p:65.

Hodge, D. M. (2004) 'Creating a virtual community of learners using Web Site: Lessons learned', Journal of Technology in Human Services, 22(3), pp. 69-78.

Hussein, Ghada(2003).The Challenges of the Modern ScientificTechnological Revolution and its Impact on Impeding the Development of Human Resources in the UAE.M.S. Cairo. Ain Shams University. Faculty of Commerce.

Ibrahim. Siraj,(2003) training based on progress, Cairo. Dar Maarif, p. (84).

James E. Phelan (2015). The Use of Electronic learning Social Work Education. Social Work Volume 60, Number 3 July 2015 
Keith ,Brownlee (2010).Have Communication Technologies Influenced Rural Social Work Practice? British Journal of Social Work (2010) 40, 622-637

Khattab. Sheriff, (2009) Human Resource Development in Modernity, Cairo, Public Authority for Books, p. (36).

Kowalenko. N, \& Whitefield. A. (2003) 'Rural workforce development and staff support: Remodeling service provision for early intervention in child and adolescent mental health', Australian Psychiatry, 11.

NASW, ASWB, CSWE, CSWA (2017) Standards for Technology in Social Work Practice

https://www.socialworkers.org/includes/newIncludes/homepage/PRA-BRO33617.TechStandards FINAL POSTING.pdf.

Page. B. J. Jencius. (2003) 'Pal Talk online groups: Process and reflections on students' experience', Journal for Specialists in Group Work, 28, pp. 35-41.

Peron, B. E., Taylor, H. O., Glass, J. E., \&Margerum-Leys, J. (2010). Information and Communication Technologies in Social Work. Advances in social work, 11(2), 67-81.

Raja Hussein Tewfik, Evaluation of Human Development Program, Master Thesis, Assiut University, Faculty of Commerce, 2007.

Rees, C. S., Gillam, D. (2001) 'Training in cognitive-behavioral therapy for mental health professionals: A pilot study of videoconferencing', Journal of Telemedicine and Tele care, 7, pp. 300-302.

Sager, Jon S. (2008) Social Planning, an article, in Terry Mizrahi and Larry E. Davis, Encyclopedia of Social Work, 20th ed,Vol (4),NASW press, Ltd, $\mathrm{p} ; 57$

Schon D.A.(1991)The reflective practitioner how professionals think in action, Alders hot Avebury

Soliman, Hussein، et al (2005): social work generalist practice with group, agency and community, Beirut university institution for publishing and distribution, 2nd edition

Wager, Marla B. (2016) Social Work and Social Welfare: An Invitation, 4th ed, New York \&London, Rout ledge, Taylore \&Francis group, p.584.

Webster, M. (2018).Empowerment.Accessfrom:https://www.merriamwebster.com/dictionary/empowerment

Webster. M. (2018). Information technology. Access from: https://www.merriamwebster.com/dictionary/information\%20technology

Zedan. Tarek,(2003) Electronic Management in Egypt, Cairo Library of the Anglo, 2002, p. 101. 